American Journal of Applied Sciences 7 (5): 698-701, 2010

ISSN 1546-9239

(C) 2010Science Publications

\title{
Density Equation of Cassava-Stalk Briquettes Under Moderate Die-Pressure
}

\author{
Patomsok Wilaipon \\ Department Mechanical Engineering, Faculty Engineering, \\ Naresuan University, Phitsanulok, Thailand 65000
}

\begin{abstract}
Problem statement: Agricultural residues seem to be the most promising energy resources for developing countries. However, the majority of them have low energy density. One of the favorable technologies for enhancing that property is briquetting. For the case of Phitsanulok, a province in Northern Thailand, cassava is one of the most important crops. Therefore, a large amount of cassava stalk is left in the field after harvest. This study was aimed to investigate the quantity of cassava stalk in this province and to study cassava stalk briquette production. Approach: The potential energy from cassava stalk was calculated based on the productivity, residue-to-product ratio, residue returned to soil ratio and its heating value. Besides, the effects of moderate-range compression pressure, 70-110 bar, and the binder ratio, $10-20 \%$, on briquette density were investigated. An empirical model was also developed and validated. Results: Base on the estimation, the quantity of usable cassava stalk in this area was approximately $18 \mathrm{kton}_{\text {year }}{ }^{-1}$. The heating value of cassava stalk was found to be $16.39 \mathrm{MJ} \mathrm{kg}^{-1}$. Therefore, the total energy over $289 \mathrm{TJ}^{\mathrm{Tear}}{ }^{-1}$ can be obtained from this agricultural waste. According to the experiment, briquette density was in the range of $0.40-0.77 \mathrm{~g} \mathrm{~cm}^{-3}$. The coefficient of multiple determination for prediction of the proposed model was about $94.7 \%$. Conclusion: It appeared that cassava stalk has high potential as energy source for this area. The density of cassava stalk briquette was increased with an increase in compaction pressure. Besides, it was found that the proposed model can be used for density prediction over the studied range.
\end{abstract}

Key words: Biomass, briquette density, cassava stalk, briquette

\section{INTRODUCTION}

For most developing countries, it appears that biomass, particularly agricultural wastes, has become one of their most promising energy sources. The idea of utilizing the residues from agricultural sectors as primary or secondary energy sources is somewhat attractive since they are available as free, indigenous and environmentally friendly ones. Furthermore, the decreasing availability of firewood has necessitated the efforts to utilize agricultural wastes efficiently and seriously. They have acquired considerable importance as fuels for many purposes viz. domestic cooking, industrial process heating and power generation. Some of them, such as coconut shell, wood chip and wood waste, are ready to be directly used as fuel. The majority of them, however, are not appropriate to be used as fuel without a suitable process since they have low density, high moisture content and low energy density. All of these issues may cause problems in transportation, handling, storage, entrained particulate emission control including direct combustion. One of the optimistic technologies for alleviating these problems is biomass briquetting, which has been studied by many researchers. The technology may be defined as a densification process for improving the handling characteristics of raw material and enhancing the volumetric calorific value of the biomass. Considerable amount of research on briquetting technology has been conducted. Examples of biomass studied are wheat straw (Demirbas, 1999a; Demirbas and Sahin, 1998), hazelnut shell (Demirbas, 1999b), woods (Granada et al., 2002; Li and Liu, 2000), grass (Finell et al., 2002; Paulrud and Nilsson, 2001), cotton (Singh, 2004; Coates, 2000), olive refuse (Yaman et al., 2000), rice straw and husk (Ndiema et al., 2002) as well as maize cob (Wilaipon, 2007).

Phitsanulok, a province in lower northern part of Thailand, is located between the latitude $16^{\circ} 21^{\prime} \mathrm{N}-$ $17^{\circ} 44^{\prime} \mathrm{N}$ and longitude $99^{\circ} 52^{\prime} \mathrm{E}-101^{\circ} 4^{\prime} \mathrm{E}$. It has an area of approximately $10,816 \mathrm{~km}^{-2}$ which is divided into nine districts, namely Muang Phitsanulok district, Nakhon Thai district, Chat Trakan district, Bang Rakam district, Bang Krathum district, Phrom Phiram district, 
Wat Bot district, Wang Thong district and Noen Maprang district. One of the major agricultural products of the province is cassava. Therefore, a considerable amount of cassava waste, such as cassava stalk, is available in this area.

The objective of this research was to investigate the effects of binder ratio and briquetting pressures on the density of cassava-stalk briquette. With regard to cassava productivity, residue-to-product ratio and residue returned to soil ratio, the quantity of cassava stalk available as energy source in Phitsanulok was also computed. Finally, by using regression technique, the relationship between the binder ratio, briquetting pressure and briquette density was developed and validated.

Cassava stalk in Phitsanulok: Cassava is one of the most important crops in Phitsanulok province. It is called as Tapioca (Manihot esculenta Crantz). Cassava plantation has been considerably popular among the Thai farmers because of an increase in cassava root demand in the market though its price has been fluctuated over time. Moreover, this kind of crop is outstanding in the adverse climate and biophysical condition. It has high tolerance to drought, diseases and insects. In addition, cassava planting and harvesting time are flexible which can maximize the farm profit (Eiumnoh and Shrestha, 1999). One of residues form cassava harvesting is its stalk. This kind of residue is left in the field after harvest. However, not all the stalk produced can be used as raw material for briquetting plant. Indiscriminate removal of the stalk can lead to decline in soil quality with long lasting adverse impacts on the environment. Some of crop residue returned to soil can improve soil quality through its impact on reducing risks of soil erosion, recycling nutrients, stabilizing soil structure, reducing soil bulk density, including improving water retention and transmission properties.

For estimating the amount of cassava stalk usable for fuel briquette production in Phitsanulok, the effects of several parameters viz. Quantity of cassava (Q), Residue-to-Product Ratio (RPR), residue Returned to Soil Ratio (RSR) are taken into account. The usable cassava stalk can be calculated from the following equation:

$$
\text { Usable cassava stalk }=(\mathrm{Q})(\mathrm{RPR})(1-\mathrm{RSR})
$$

In this study, the RPR value of 0.88 and the RSR value of 0.593 (Sajjakulnukit et al., 2005) were utilized for cassava stalk estimation purpose. The average value of usable residue was about $18 \mathrm{kton}_{\text {year }}{ }^{-1}$. The results of the calculation are also shown in Fig. 1.

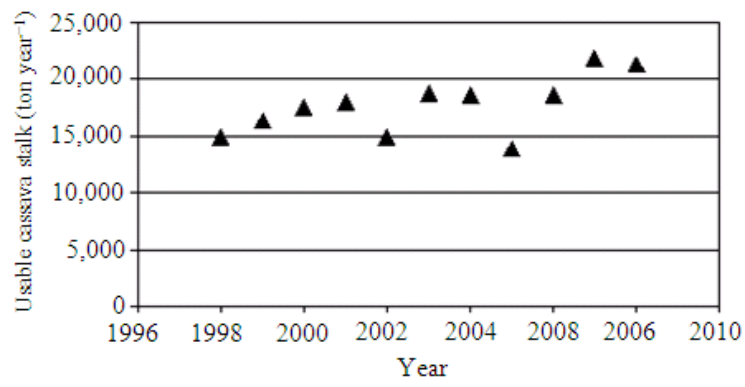

Fig. 1: Calculated amount of cassava stalk available as energy source in Phitsanulok, Thailand

\section{MATERIALS AND METHODS}

The heating value of cassava stalk utilized in the experiment was examined. The Parr isoperibol bomb calorimeter with an accuracy of $0.0001^{\circ} \mathrm{C}$ was used for that purpose. The moisture content of cassava stalk was studied according to ASAE S269.4 method. The raw material utilized in the experiments was obtained from three sites in Phitsanulok during 2009.

Biomass briquettes were produced in the laboratory of Biomass Energy Research Unit, Engineering Faculty, Naresuan University. First, cassava stalk was air dried and cut into small pieces. The particles larger than $2 \mathrm{~mm}$ were removed before briquetting by using a sieve with an accuracy of $\pm 0.025 \mathrm{~mm}$. In this study, starch was selected as the binder since it is one of products produced from cassava. Three levels of binder ratio viz. 10,15 and $20 \%$ were utilized. Starch at specified amount was made into paste with hot water. Then, cassava stalk was mixed with the binder by using an electric mixer. The mixing process was carried on until mould-condition was achieved. The well mixed material was preheated to $80^{\circ} \mathrm{C}$ for $2 \mathrm{~min}$ before compaction.

For each sample, $20 \mathrm{~g}$ of the preheated mixture was compacted at ambient temperature by using a calibrated laboratory-scale hydraulic press. A pressure switch with an accuracy of $1 \%$ was used to control the pressure of hydraulic machine. A harden steel with an inner diameter of $38 \mathrm{~mm}$ and a height of $200 \mathrm{~mm}$ was utilized as a die for producing cassava stalk briquettes. The briquetting pressure range in the experiments was from 70-110 bar. In addition, the dwell time was set to be $1 \mathrm{~min}$ throughout the experiments. Three briquettes were prepared for each set of the experimental conditions.

Least-squares technique was used for developing an empirical model of biomass-coal briquette density over the studied range. Normal probability plot of the 
residuals was used for checking the normal distribution of the residuals. Then, the multiple correlation coefficient; $\mathrm{R}^{2}$, the adjusted coefficient of determination; $\mathrm{R}^{2}$ adjusted and the coefficient of multiple determination for prediction; $R_{\text {prediction were used as }}^{2}$ criteria for model adequacy checking.

\section{RESULTS}

According to the heating value study, it was found that the heating value of cassava stalk was about $16.39 \mathrm{MJ} \mathrm{kg}^{-1}$. The moisture content of raw materials was found to be $15.62 \%$. From the calculation, the estimated energy values of cassava stalk available in Phitsanulok during 1998-2008 was from 229-359 TJ year $^{-1}$. The average value of the potential energy during 2006-2008 was approximately 338 TJ year ${ }^{-1}$. Additionally, the highest value was accounted for 2007's record.

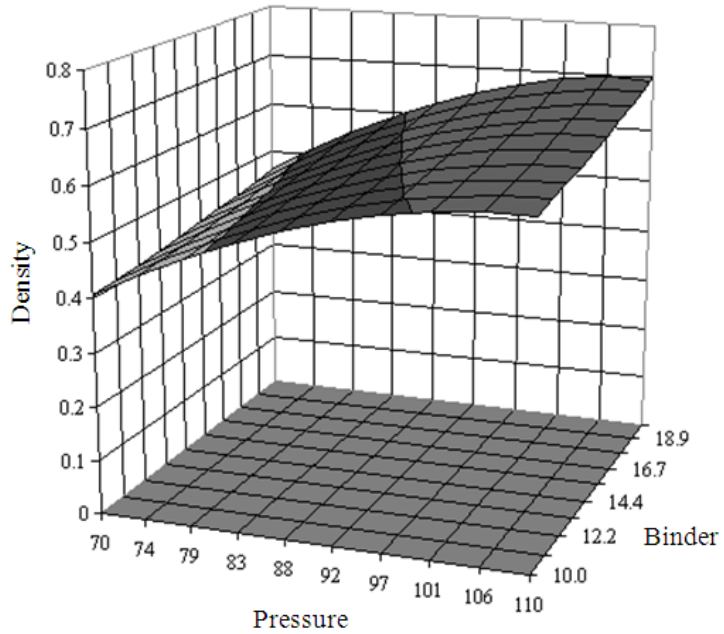

Fig. 2: Model adequacy checking (expected normal value Vs standardized residuals)

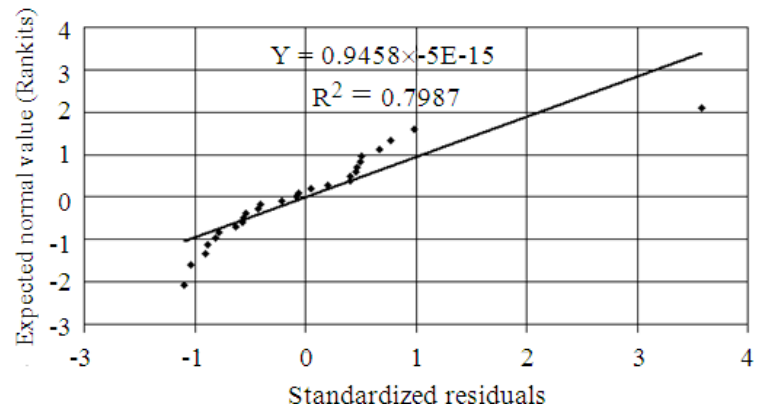

Fig. 3: Model adequacy checking (expected normal value Vs standardized residuals)
The density of produced cassava stalk briquettes was in the range of $0.40-0.77 \mathrm{~g} \mathrm{~cm}^{-3}$. By using regression technique, the relationship between density, briquetting pressure and binder percentage over the studied range was developed. The empirical variable, response, was the density while the independent variables were briquetting pressure (70-110 bar) and binder percentage (10-20\%), respectively:

$\mathrm{D}=-0.9865+0.02905 \mathrm{P}+2.72\left(10^{-6}\right) \mathrm{PB}^{2}-0.00013 \mathrm{P}^{2}$

Where:

$\mathrm{D}=$ Density $\left(\mathrm{g} \mathrm{cm}^{-3}\right)$,

$\mathrm{P}=$ Briquetting pressure (bar)

$\mathrm{B}=$ Binder percentage $(\%)$

Besides, it was found that the values were increased with an increase in briquetting pressure as can be seen from Fig. 2.

For model adequacy checking purpose, the coefficient of multiple determination, $\mathrm{R}^{2}$ and the adjusted coefficient of determination, $\mathrm{R}_{\text {adjusted, were }}^{2}$ used to investigate the quality of fit. In addition, by using the prediction error sum of squares, the coefficient of multiple determination for prediction, $\mathrm{R}^{2}$ prediction, was also studied. According to the calculations, the values of $\mathrm{R}^{2}, \mathrm{R}^{2}$ adjusted and $\mathrm{R}^{2}$ prediction are $0.964,0.959$ and $0.947 \%$ respectively. Finally, a graph between expected normal value and standardized residuals was also plotted as shown in Fig. 3.

\section{DISCUSSION}

It seems that the quantity of usable cassava stalk in this area was in the moderate range since some of the residue must be returned to soil for improving its quality. However, this waste can be used for briquette production. Several kton of wood fuel utilization can be replaced by using cassava briquette. According to the density, it shows that the modest range of compaction pressure can be used to produce moderate-density cassava stalk briquettes. With regard to the proposed

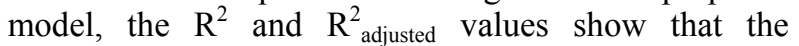
proposed relationship was not over-fitted while the

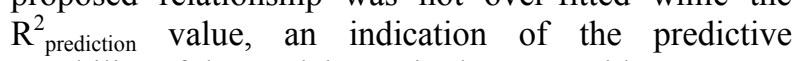
capability of the model, was in the acceptable range.

\section{CONCLUSION}

One of the most important agricultural products of Phitsanulok, a province in Thailand, is cassava. According to the average productivity of cassava

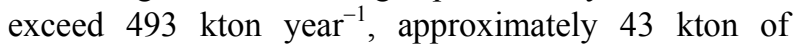


cassava stalk has been generated. The estimated value of usable cassava stalk as energy sources was about $18 \mathrm{kton} \mathrm{year}^{-1}$. According to its heating value, the calculated amount of potential energy from this agricultural waste was over $289 \mathrm{TJ}^{\mathrm{Tear}}{ }^{-1}$. Therefore, cassava stalk is one of the most promising agricultural residues which can be used as fuel. With respect to cassava stalk fuel production, the relationship between the density and briquetting pressure as well as binder ratio was investigated. According to the studied range, it was found that the briquette density was strongly affected by compaction pressure. In addition, the density model was also developed and validated. The model adequacy checking showed that the proposed equation gave a good result in density prediction.

\section{ACKNOWLEDGEMENT}

The researcher would like to acknowledge Engineering Faculty, Naresuan University for providing the grant to support this research.

\section{REFERENCES}

Coates, W., 2000. Using cotton plant residue to produce briquettes. Biomass Bioenergy, 18: 201-208. DOI: 10.1016/S0961-9534(99)00087-2

Demirbas, A. and A. Sahin, 1998. Evaluation of biomass residue 1: Briquetting waste paper and wheat straw mixtures. Fuel Process. Technol., 55: 175-183. DOI: 10.1016/S0378-3820(98)00041-1

Demirbas, A., 1999a. Physical properties of briquettes from waste paper and wheat straw mixtures. Energy Convers. Manage., 40: 437-445. DOI: 10.1016/S0196-8904(98)00111-3

Demirbas, A., 1999b. Properties of charcoal derived from hazelnut shell and production of briquettes using pyrolytic oil. Energy, 24: 141-150. DOI: 10.1016/S0378-3820(98)00041-1

Eiumnoh, A. and R.P. Shrestha, 1999. A study on estimation of cassava area and production using remote sensing and geographic information systems in the northeast region of Thailand. Southeast Asian Stud., 37: 417-430. http://www.cseas.kyoto-u.ac.jp/seas/37/3/370305.pdf
Finell, M., C. Nilsson, R. Olsson, R. Agnemo and S. Svensson, 2002. Briquetting of fractioned reed canary-grass for pulp production. Ind. Crops Prod., 16: 185-192. DOI: 10.1016/S0926-6690(02)00036-5

Granada, E., L.M.L. Gonzalez, J.L. Miguez and J. Moran, 2002. Fuel lignocellulosic briquettes, die design and products study. Renew. Energy, 27: 561-573. DOI: 10.1016/S0960-1481(02)00005-8

Li, Y. and H. Liu, 2000. High-pressure densification of wood residues to form an upgraded fuel. Biomass Bioenergy, 19: 177-186. DOI: 10.1016/S09619534(00)00026-X

Ndiema, C.K.W., P.N. Manga and C.R. Ruttoh, 2002. Influence of die pressure on relaxation characteristics of briquetted biomass. Energy Convers. Manage., 43: 2157-2161. DOI: 10.1016/S0196-8904(01)00165-0

Paulrud, S. and C. Nilsson, 2001. Briquetting and combustion of spring-harvested reed canary-grass: Effect of fuel composition. Biomass Bioenergy, 20: 25-35. DOI: 10.1016/S0961-9534(00)00061-1

Sajjakulnukit, B., R. Yingyuad, V. Maneekhao, V. Pongnarintasut, S.C. Bhattacharya and P.A. Salam, 2005. Assessment of sustainable energy potential of non-plantation biomass resources in Thailand. Biomass Bioenergy, 29: 214-224. DOI: 10.1016/j.biombioe.2005.03.009

Singh, R.N., 2004. Equilibrium moisture content of biomass briquettes. Biomass Bioenergy, 26: 251253. DOI: $10.1016 / \mathrm{S} 0961-9534(03) 00082-5$

Wilaipon, P., 2007. Physical characteristics of maize cob briquette under moderate die pressure. Am. J. Applied Sci., 4: 995-998. http://www.scipub.org/fulltext/ajas/ajas412995998.pdf

Yaman, S., M. Sahan, H. Haykiri-acma, K. Sesen and S. Kucukbayrak, 2000. Production of fuel briquettes from olive refuse and paper mill waste. Fuel Process. Technol., 68: 23-31. DOI: 10.1016/S0378-3820(00)00111-9 